\title{
Nutritional Analysis of Selected Cucurbitaceae Species
}

\author{
Ogunbanjo O.R.", Awotoye O.O., Jayeoba F.M., Jeminiwa S.M. \\ Department of Basic Sciences and General Studies, Federal College of Forestry, Nigeria
}

Copyright $(2015$ by authors, all rights reserved. Authors agree that this article remains permanently open access under the terms of the Creative Commons Attribution License 4.0 International License

\begin{abstract}
The global consumption of conventional feed resources is presently close to production, therefore the need to search for alternative cum additional feed ingredients become imperative. Cucurbitaceae are flowering plants that occur in the tropical and sub-tropical vegetation, primarily in rainforest, vine thickets and sparsely vegetated rocky outcrops. This study explored the nutritional potential of the seeds of six selected Cucurbitaceae species: Cucurbita pepo, Cucumeropsis manii, Luffa cylindrica, Lagenaria scicereria, Adenopus breviflorus and Citrullus lanatus as feed resource. Pods of the six Cucurbitaceae species were from major markets across various parts of Oyo State, Nigeria. Results from the proximate analysis of the seeds revealed that there were significant $(\mathrm{p}<0.05)$ differences among the samples in all the parameters (moisture content, crude fibre, ash, protein, carbohydrate and fat) considered. Lagenaria sicereria recorded the highest values in crude protein, fat and ash content of $27.80 \%, 48.75 \%$ and $4.25 \%$ respectively while it had the least percentage moisture content $(7.30 \%)$. Percentage carbohydrate content was highest in Luffa cylindrica (22.20\%). Cucurbitaceae species could serve as an alternative feed stuff in animal nutrition when supplemented with other materials.
\end{abstract}

Keywords Nutritional, Proximate, Rainforest, Feedstuff

\section{Introduction}

The tropical rainforests covers $7 \%$ of the world land area; they sustain the richest concentrations of plant and animal diversity. The tropical rainforests serve as sources of timber, medicinal plants and carbon sinks while also playing a critical role in watershed protection (Richards, 1996). Around $40 \%$ to $75 \%$ of all biotic species are indigenous to the rainforests. Rainforests are home to half of all the living animal and plant species on the planet. Two-thirds of all flowering plants have been found in this habitat. It is reported that the tropical forests have supplied about 250 cultivated kinds of fruit, compared to only 20 for temperate forests (Myer, 1985).

Forests and trees have contributed to household food security and nutrition by providing diet diversity and consequently improving the quantity and quality of food intake. Trees and shrubs have also played a role in feeding livestock. They are increasingly recognized as important components of animal feeding, especially as suppliers of protein (Atiya et al, 2011). Forest foods provide a wide variety of nutrients: carbohydrates, protein, fats and micronutrients (vitamins and minerals).

Cucurbitaceae are flowering plants that occur in the tropical and sub-tropical vegetation, primarily in rainforest, vine thickets and sparsely vegetated rocky outcrops (Yamaguchi, 1983). Cucurbitaceae is an important family comprising one of the most genetically diverse groups of food plants. There are nearly 100 genera and more than 750 species in the family. They are annual or perennial vines that either trail along the ground or climb upwards using tendrils. The different species of Cucurbitaceae have served humans for over 10,000 years as important foods and as many useful products (Ajuru and Okoli, 2013). In Nigeria, they are used for different purposes in different parts of the country.

Several plants exist with very high nutritive values that are yet to be exploited for human and animal benefits (Oladele and Oshodi, 2007). As the global consumption of conventional feed resources such as cottonseed, rapeseed, soybean and sunflower seed is on the increase, it is necessary to urgently search for alternative/additional feed ingredients (USDA, 2011).

This study explores the nutritional potential of the seeds of six selected Cucurbitaceae specie: Cucurbita pepo, Cucumeropsis manii, Luffa cylindrica, Lagenaria scicereria, Adenopus breviflorus and Citrullus lanatus as feed resource.

\section{Materials and Methods}

Collection and Identification of samples: Pods of the six selected Cucurbitaceae species were obtained from major markets across various parts of Oyo state, Nigeria. The pods were identified and classified at the Forest Herbarium, Forestry Research Institute of Nigeria (FRIN). The pods were slit open and the seeds scooped out and air dried.

Proximate analysis: The methods of the Association of Official Analytical Chemists were used for determination of moisture, crude fibre, protein and fat content of the samples. All determinations were done in duplicates. The proximate 
values were reported in percentage.

Determination of moisture content was done by weighing $5 \mathrm{~g}$ of each sample (in duplicate) in crucible and drying in oven at $105^{\circ} \mathrm{C}$, until a constant weight was obtained. Determination of ash content was done by ashing at $550^{\circ} \mathrm{C}$ for about $3 \mathrm{hr}$. The Kjeldah method was used to determine the protein content by multiplication of the nitrogen value with a conversion factor (6.25). The crude fibre content of the samples was determined by digestion method and the lipid was done by Soxhlet extraction method (AOAC, 1990).

The crude fat content of the seed samples were determined using the Soxhlet extraction apparatus, to thoroughly extract the crude fat from $4.0 \mathrm{~g}$ of milled sample using petroleum ether (boiling point $40^{\circ} \mathrm{C}-60^{\circ} \mathrm{C}$.

Total soluble carbohydrate was determined by the difference of the sum of all the proximate composition from $100 \%$.

Statistical Analysis: The data gotten from the proximate analysis were subjected to one-way analysis of variance using the statistical package for the social sciences. Significant means were separated using Duncan multiple range test (Akindele, (1996)

\section{Results and Discussion}

Results obtained from the proximate analysis of the selected Cucurbitaceae seeds revealed that there were significant $(p<0.05)$ differences among the samples in all the parameters considered (moisture content, crude fibre, ash, protein, carbohydrate and fat).

The moisture content of a seed is the most vital parameter, which influences the seed's quality and storage life. Moisture content was highest in Cucumeropsis manii (9.75\%) and least in Lagenaria scicereria (7.30\%). Citrullus lanatus and Adenopus breviflorus both recorded a moisture content of $8.45 \%$. This implies that Cucumeropsis manii seeds may have the lowest storability potential while Lagenaria scicereria seeds will be easier preserved. The moisture content recorded for all the species are lower than those reported for soybean (11.07\%) and coconut seeds (14.3\%) (FAO, 1982).

The ash content of the six seeds are significantly different $(\mathrm{p}<0.05)$ with Lagenaria scicereria having the highest value of $4.25 \%$. Citrullus lanatus had the lowest value of $3.15 \%$.The ash content of Cucumeropsis manii and Adenopus breviiflorus are not significantly different from each other. The values are within the range obtained for cotton seed (4\%) sesame (3.8\%) and the seeds and kernels of some Cucurbitaceae specie (Achu et al (2005). The ash content of all the seeds are lower than 5.00\% reported for Terminalia catappa (Akpabio, 2012).

The fat content of the samples ranged between $41.8 \%$ $48.75 \%$, Lagenaria scicereria recorded the highest fat content of $48.75 \%$. These values are higher than that obtained by Paul and Southage (1980) for soybean 23.05\% and cottonseed. The values were within the range obtained by Ige et al (1984) for other species of melon oil seeds (45\%-51\%). The fat content of the Cucurbitaceae specie were lower than $58.23 \%$ obtained for Bombax glabrum.

Protein content was highest in Lagenaria sicereria and lowest in Luffa cylindrica. The values for protein compares favourably with those protein rich food such as soybean, cowpea and pumpkin with protein content ranging between 23.10 and 33.00 (Olaofe et al, 1994). The values obtained for the six specie are higher than those reported for Acacia robusta (12.52\%) and Acacia erubescens (21.8\%) and Bombax glabrum (10.23\%) seed kernels (Adeleke and Abiodun, 2010). The values obtained for whole seeds are similar to those of Achu et al., (2005) and Martin (1998) who reported them to contain 29\%-35\%. Martin (1998) reported $35 \%$. The results were higher than the protein content of cashew nuts (22.8\%) and sesame (18.8\%). The fluted pumpkin (Telfaria occidentals) seed was reported to contain $30.1 \mathrm{~g} / 100 \mathrm{~g}$ protein (Asiegbu, 1987).

The crude fiber contents of $1.50 \%-2.20 \%$ that were recorded among the Cucurbita specie were low when compared with cottonseed (5\%-25\%), soybean $(9.30 \%)$,and watermelon seeds $29.7 \%-30.9 \%$ (Suarez et al.1999, Hafeni et al, 2013).

The carbohydrate content of the seeds was low (10.10\%-22.20\%) when compared to other oilseed such as soybean and groundnut (Adeleke and Abiodun, 2010). Percentage carbohydrate content was highest in Luffa cylindrica (22.20\%).

Table 1. Proximate composition of selected Cucurbitaceae seeds

\begin{tabular}{|c|c|c|c|c|c|c|}
\hline Species & Moisture content $(\%)$ & Ash (\%) & Fat $(\%)$ & Crude protein $(\%)$ & Crude fibre $(\%)$ & Carbohydrate $(\%)$ \\
\hline Cucurbita pepo & 8.20 & 3.55 & 46.05 & 23.35 & 2.20 & 16.65 \\
\hline Cucumeropsis manii & 9.75 & 3.75 & 45.20 & 24.3 & 1.75 & 11.75 \\
\hline Lagenaria scicereria & 7.30 & 4.25 & 48.75 & 27.80 & 1.80 & 10.10 \\
\hline Luffa cylindrica & 7.45 & 3.60 & 41.80 & 22.90 & 1.95 & 22.20 \\
\hline Adenopus breviflorus & 8.45 & 3.90 & 47.30 & 27.15 & 1.70 & 11.30 \\
\hline Citrullus lanatus & 8.45 & 3.15 & 47.00 & 22.95 & 1.50 & 16.95 \\
\hline Mean & 8.27 & 3.70 & 46.10 & 25.24 & 1.82 & 14.83 \\
\hline Sig & $<0.00$ & $<0.00$ & $<0.00$ & $<0.00$ & $<0,00$ & $<0.00$ \\
\hline S.E & 0.23 & 0.10 & 0.65 & 0.66 & 0.07 & 1.27 \\
\hline
\end{tabular}




\section{Conclusions}

The seeds of the Cucurbitaceae specie could serve as an alternative feed stuff in animal nutrition when supplemented with other materials as it compared favourably with other conventional feed stuff in percentage protein, ash and carbohydrate.

\section{REFERENCES}

[1] Achu B.M., Fokou E.and Martin F. (2005): Nutritive value of some Curcubitaceae oil seeds from different regions in Cameroon. African Journal of Biotechnology 4:1329 - 1334.

[2] Adeleke R.O. and Abiodun O.A. (2010): Nutritional and physicochemical properties of Bombax glabrum seeds. Pakistan Journal of nutrition 9(9) 856-857

[3] Ajuru M.G. and Okoli B. E. (2013): The Morphological Characterization of the Melon Species in the Family Cucurbitaceae Juss., and their Utilization in Nigeria International Journal of Modern Botany 3(2):15-19

[4] Akindele, S.O.(1996). Basic Experimental Designs in Agricultural Research. Montem Paperbacks, Akure, Nigeria.(ISBN 978-32973-8-4).102pp.

[5] Akpabio U.D (2012):Evaluation of proximate composition, mineral element and anti- nutrient in almond (Terminalia catappa) seeds. Advances in Applied Science Research 3 (4):2247-2252

[6] AOAC. (1990): Official methods of analysis, Association of Official Analytical Chemists, Washington, D.C., USA. 15th Edition, pp. 807-928.

[7] Asiegbu J. E (1987): Some biochemical evaluation of fluted pumpkin seed. Journal of the Science of Food and Agriculture 40:151-155.

[8] Atiya A., Shakira G., Asma L. and Mukhtar A. N. (2011): Nutritional Evaluation of Some Top Fodder Tree Leaves and Shrubs of District Chakwal, Pakistan in Relation to Ruminants Requirements. Pakistan Journal of Nutrition 10 (1): 54-59,

[9] FAO (1982): Food composition table for the Near East; nut and seeds. FAO Food and Nutrition Paper 26:86.

[10] Fedha M.S., Mwasaru M.A., Njoroge C. K, Ojijo, N. O. and Ouma, G. O.(2010): Effect of drying on selected proximate composition of fresh and processed fruits and seeds of two pumpkin species. Agriculture and biology journal of North America 1(6): 1299-1302

[11] Hafeni S., Mpofu I.D.T. and Petrus P. (2013): The potential of pearl millet and water melon seeds as cheap alternative ingredients in Namibian poultry feeds Agricultural Science Research Journal 3(5); pp. 140-143

[12] Ige, M.N., Ogunsua, A.O. and Okon, O.L. (1984): functional properties of the protein of some Nigeria oil seeds. Casophor seeds and three varieties of some Nigeria oil seeds. Food Chem., 32: $822-825$.

[13] Martin F. (1998): Cucurbit seeds as possible oil and protein sources for small scale household use in the hot humid tropics. Oil crops/processing pp2

[14] Myer N.(1985):The primary source .W.W. Nortorn and Co., NewYork pp.189-193

[15] Oladele P.E and Oshodi A.A (2007): Nutritional potential of Berlandier Nettle Spurge (Jatropha cathartica) seed. Pakistan Journal of Nutrition 6:345-348

[16] Olaofe, O., Adeyemi, F.O. and Adediran, G. O. (1994): Amino acid and mineral composition and functional properties of some oil seeds. Journal of Agric Food Chemistry 42: 878-881.

[17] Paul, A.A. and Southgate , B.A.T. (1980): Mucance and Widdowson's Composition of Food, 4 th edition, Her Majesty's stationary office, London . Uk , pp: 227- 228.

[18] Suarez FL, Spring-Field J, Furne JK, Lohrmann TT, Kerr PS, Levitt MD. Gas production in human ingesting soybean flour derived from bean naturally low in oligosaccharides Am J. Clin Nutr. 1999: 69.135-140

[19] Richards T.W. (1996): The tropical rain forest: An ecological study. Cambridge University Press, pg 575.

[20] USDA (2011): Oilseeds: World markets and trade, foreign agricultural service. (http://usda.mannlib.cornell.edu/MannUsda/viewDocumentI nfo

[21] Yamaguchi M. (1983): World Vegetables: Principles, Production and Nutritive values: West port, Conn. 